Biến chứng chảy máu trước phẫu thuật chiếm $39 \%$, trong và sau phẫu thuật có 6 trường hợp mổ chủ động thai to, khối âm vang hỗn hợp sau điều trị mổ có biến chứng chảy máu phải truyền máu. Theo Đinh Quốc Hưng [5] tỷ lệ biến chứng chảy máu là 18,3\%, theo Phạm Thị Hải Yến [6] là $14,8 \%$. Có 14 trường hợp phải truyền máu, chiếm $23,7 \%$, có $6 / 14$ trường hợp truyên máu do mất máu trong quá trình phẫu thuật, $8 / 14$ trường hợp nguyên nhân rất khó phân định do triệu chứng ra máu lâu ngày, băng huyết, điều trị trước đó hay do trong quá trình phầu thuật, hoặc kết hợp các quá trình trên. Theo Đinh Quốc Hưng [5] tỷ lệ truyền máu 14,1\%, theo Diêm Thị Thanh Thủy [7] là $11,8 \%$. Sở dĩ biến chứng chảy máu, truyền máu của chúng tôi cao hơn hẳn các nghiên cứu khác vì nghiên cứu của chúng tôi chỉ nghiên cứu các trường hợp phẫu thuật. Có 2 trường hợp mổ lại do tổn thương cơ quan tiêu hóa và do tổn thương bàng quang. Trong quá trình mổ, tiến hành mổ mở lấy khối chửa vì chảy máu nhiêu nên phải cắt tử cung bán phần, sau mổ chảy máu, mổ lại phát hiện gai rau đâm xuyên bàng quang, tổn thương bàng quang.

\section{KẾT LUẬN}

Phẫu thuật các trường hợp chửa sẹo mổ lấy thai chủ yếu là mổ lấy khối chửa bảo tồn tử cung.

\section{TÀI LIẸU THAM KHẢO}

1. Wang, Y.L., et al., Laparoscopic management of ectopic pregnancies in unusual locations. Taiwan J Obstet Gynecol, 2014. 53(4): p. 466-70.

2. Ghezzi, F., et al., Conservative treatment by chemotherapy and uterine arteries embolization of a cesarean scar pregnancy. Eur J Obstet Gynecol Reprod Biol, 2002. 103(1): p. 88-91.

3. Timor-Tritsch, I.E., et al., The diagnosis, treatment, and follow-up of cesarean scar pregnancy. Am J Obstet Gynecol, 2012. 207(1): p. 44 e1-13.

4. Lee, C.L., et al., Laparoscopic management of an ectopic pregnancy in a previous Caesarean section scar. Hum Reprod, 1999. 14(5): p. 1234-6.

5. Đinh Quốc Hưng (2011), Nghiên cứu chửa ở seo mố lấy thai tại Bệnh viện Phụ Sản Trung Ương,. Trướng đại học Y Hà Nội.

6. Phạm Thi Hải Yến (2014), Đánh giá kết quả điều trị chửa sẹo mổ lấy thai bằng MTX/ hút thai tại bệnh viện Phụ Sản Trung Ương từ tháng 01 năm 2014 đến tháng 9 năm 2014, Đại học Y Hà Nội.

7. Diêm thị Thanh Thuỷ (2013), Nghiên cứu chửa sẹo mổ lây thai tại bệnh viện phụ sản Hà Nội, Trường đại học Y Hà Nội.

\title{
PHÂN TÍCH KẾT QUẢ KINH DOANH CÁC NHÓM THUỐC CHỐNG NHIỄM KHUẨN, TAI MŨI HONG, MẮT CỦA CÔNG TY TRÁCH NHIỆM HỮU HẠN DƯợC PHẨM XUÂN HÒA NĂM 2017-2018
}

\section{TÓM TẮT}

Đặt vấn đề: Phân tích hoat đông kinh doanh của doanh nghiệp dược là cần thiết để nhìn nhận những điểm đã làm tốt và một số hạn chế để từ đó có giải pháp phù hợp cho doanh nghiệp phát triển trong những năm tiếp theo. Theo đó, Phân tích kết quả hoạt động kinh doanh của Công ty TNHH Dược phẩm Xuẩn Hoà năm 2017-2018 là cần thiết. Đối tượng và phương pháp: các mặt hàng thuốc, thực phẩm chức năng kinh doanh của công ty TNHH Dược phẩm Xuân Hòa năm 2017 và năm 2018. Phương pháp nghiên cứu: mô tả cắt ngang hồi cứu số liệu. Kết quả: Doanh thu của Công ty TNHH Dược phẩm Xuân Hòa năm 2018 với 50 sản phẩm đạt 122.598 tỷ đồng, đạt 87,61 so với năm 2017 với 47 sản phẩm (đạt 139.925 tỷ VND). Nhóm thuốc Hóa dược kinh doanh của công

*Đại Hoc Dước Hà Nội

Chịu trách nhiệm chính: Bùi Việt Dũng

Email: buivietdung2904@gmail.com

Ngày nhận bài: 19.4.2021

Ngày phản biên khoa học: 28.5.2021

Ngày duyệt bài: 15.6.2021
Bùi Việt Dũng*, Đỗ Xuân Thắng*

ty năm 2018 là 48 sản phẩm đạt doanh thu là 116,768 tỷ VND chiếm tỷ trọng $87,3 \%$ thấp hơn so với năm 2017 (134.784 tỷ đồng). Doanh thu bán hàng tập trung vào một số nhóm thuốc chủ đạo là nhóm thuốc điều trị mắt, tai mữi họng với 3 sản phẩm đạt doanh thu là 28,583 tỷ đồng năm 2018, giảm hơn so với năm 2017 (doanh thu đạt 39,932 tỷ đông). Tiếp theo là nhóm chống nhiễm khuẩn có 5 sản phẩm với doanh thu năm 2018 đạt 24,754 tỷ VND tăng hơn so với năm 2017 (doanh thu đạt 15,224 tỷ đồng). Thuốc kinh doanh theo nguồn gốc sản xuất trong nước năm 2017 có 45 sản phẩm doanh thu đat 130,899 tỷ chiếm $93,5 \%$, tới năm 2018 có 47 sản phẩm doanh thu đat 113,586 tỷ đồng. Đối với nhóm hàng nhập khẩu năm 2017 có 2 sản phẩm, giá trị đạt đước là 9,026 tỷ chiếm tỷ lê $4 \%$ tổng doanh thu, năm 2018 có 3 sản phẩm giá trị đạt được 9,012 tỷ chiếm $6 \%$ tổng doanh thu. Lợi nhuận và tỷ suất lợi nhuận đạt mức thấp trong năm 2018 khi so với 2017. Tỷ suất lợi nhuận trên doanh thu thuần LN/DTT (ROS) đạt ở mức thấp 0,01\% năm 2018. Tỷ suất lợi nhuận trên VCSH (ROE) của Công ty năm 2018 đạt $0,11 \%$. Kết luận: Công ty cần tìm kiếm thêm các nguồn hàng có lợi thế cạnh tranh để tăng hiệu quả kinh doanh của công ty trong các năm tiếp theo. 


\section{SUMMARY \\ ANALYSIS OF BUSINESS ACTIVITIES OF MEDICINE GROUPS: ANTI-INFECTION, EAR NOSE THROAT, EYES OF XUAN HOA PHARMACEUTICAL COMPANY LIMITED FROM THE YEAR 2017 TO 2018}

Background: Analyzing business results of pharmaceutical enterprises is necessary to recognize the positive point and some limitations for taking solutions for the business development in the coming years. Accordingly, it is necessary to analyze the business results of Xuan Hoa Pharmaceutical Co., Ltd in 2017-2018. Subjects and methods: medicinal products, functional foods of Xuan Hoa Pharmaceutical Co., Ltd. in 2017 and 2018. Research method: retrospective cross-sectional description. Result: Revenue of Xuan Hoa Pharmaceutical Co., Ltd in 2018 with 50 products reached 122,598 billion VND, making up 87.61 percent in 2017 with 47 products (approximately 139,925 billion VND). The sales of pharmaceutical and chemical drugs in 2018 with 48 products was VND 116,768 billion, accounting for 87.3 percent, lower than in 2017 (VND 134,784 billion). Revenue focused on the number of key chemical drugs namely eye, ear, nose and throat medicine, reached VND 28,583 billion in 2018, lower than 2017 (sales reached VND 39,932 billion). Then, the antiinfection with 5 products made a profit of VND 24,754 billion in 2018, increased to 2017 (VND 15,224 billion). In 2017, there were 45 products with sales of 130.899 billion VND, accounting for 93.5\%, in 2018 there were 47 products with revenue of 113,586 billion VND. For the group of imported goods in 2017 with 2 products, the sales was at 9,026 billion VND, accounting for $4 \%$ of total revenue. In 2018 there were 3 products with the value of 9,012 billion VND, accounting for $6 \%$ of total revenue. Profit and profit margin reached the lowest level in 2018 compared to 2017. Return on sales (ROS) was low at $0.01 \%$ in 2018 . Return on equity (ROE) of the company in 2018 reached $0.11 \%$. Conclusion: The company should seek more sources of products with competitive advantages to increase efficient activities in the following years.

\section{I. ĐĂT VẤN ĐỀ}

Chiến lược quốc gia phát triển ngành Dược Việt Nam Giai đoạn 2020 và tầm nhìn đến năm 2030 (quyết định số 68/QĐ-TTG) đã hoạch định chiến lược phát triển cho ngành dược Việt nam [1]. Theo đó, các công ty Dược phẩm trong nước đứng trước những cơ hội to lớn để phát triển, bên cạnh đó cũng phải đối mặt với không ít những thách thức do sự cạnh tranh ngày càng khốc liệt. Với bản chất của nền kinh tế thị trường, các doanh nghiệp Dược muốn duy trì và phát triển bền vững cần phải có các phương án để nâng cao khả năng cạnh tranh và thích ứng với sự biến động của các điều kiện kinh tế- xã hội. Nhà quản lí cần phải am hiểu thị trường, nẳm bắt kịp thời các thông tin, cùng với đó phải có những phân tích và đánh giá cụ thể về quá trình hoạt động cũng như kết quả kinh doanh của doanh nghiệp [6]. Do vậy, phân tích hiệu quả hoạt động kinh doanh là rất quan trọng và cân thiết đối với mọi doanh nghiệp. Công ty TNHH Dược Phẩm Xuân Hòa là một doanh nghiệp nhỏ, năm 2017 Công ty có một số mặt hàng độc quyền phân phối, tuy nhiên sang năm 2018, một số mặt hàng hết hợp đồng độc quyền và công ty đối mặt với những khó khăn và thách thức lớn. Để tồn tại và phát triển, công ty đã và đang từng bước khắc phục những khó khăn, đề ra những mục tiêu cũng như chiến lược kinh doanh phù hợp trong tình hình mới.

Phân tích hoạt động kinh doanh của công ty trong 2 năm từ 2017-2018, nhìn nhận lại những gì đã làm được và chưa làm được, cũng như thuận lợi và khó khăn trong quá trình hoạt động, từ đó đề xuất một số giải pháp với hy vọng góp phần đổi mới hoạt động của công ty, giúp công ty ngày càng đứng vững và lớn mạnh trong tương lai, nghiên cứu: "Phân tích kết quả hoạt động kinh doanh của Công ty TNHH Dược phẩm Xuân Hoà năm 2017-2018" được thực hiện với muc tiêu: So sánh cơ cấu danh muc thuốc và kết quả kinh doanh của công ty TNHH Dược phẩm Xuân Hòa năm 2017 với năm 2018.

\section{II. ĐỐl TƯƠNG VÀ PHƯƠNG PHÁP NGHIÊN CỨU \\ 2.1 Đối tượng nghiên cứu. Toàn bộ các} mặt hàng thuổc, thực phẩm chức năng kinh doanh của công ty TNHH Dược phẩm Xuân Hòa năm 2017 và năm 2018. Báo cáo tài chính và báo cáo bán hàng của công ty.

2.2 Phương pháp nghiên cứu. Phương pháp mô tả cắt ngang thông qua hồi cứu số liệu từ báo cáo, chứng từ liên quan đến kết quả kinh doanh năm 2017 và năm 2018 của công ty TNHH Dược Phẩm Xuân Hòa.

Mẫu nghiên cứu: là toàn bộ mặt hàng kinh doanh (xuất kho) tại Công ty TNHH Dược Phẩm Xuân Hòa trong giai đoạn 2017 đến 2018.

Xử lý và phân tích số liệu: Số liệu được xử lý bằng phần mềm Microsoft Excel 2016 và phân tích theo phương pháp tỷ trọng và phương pháp so sánh. Kết quả nghiên cứu được trình bày dưới dạng bảng, biểu trên phần mềm Microsoft Word 2016.

\section{KẾT QUẢ NGHIÊN CứU}

Cơ cấu danh mục hàng kinh doanh của công ty năm 2017-2018

Cơ cấu hàng theo tính chất danh mục hàng kinh doanh của công ty gồm 2 nhóm: Thuốc Hóa dược và thực phẩm chức năng. 
Bảng 3.1: Cơ câu hàng hóa kinh doanh của công ty

\begin{tabular}{|c|c|c|c|c|c|}
\hline \multirow{2}{*}{\multicolumn{2}{|c|}{ Chủng loại hàng }} & \multirow{2}{*}{2017} & \multirow{2}{*}{2018} & \multicolumn{2}{|c|}{ Tỷ lệ so sánh } \\
\hline & & & & Tỷ lệ đạt & Tăng giảm \\
\hline \multirow{4}{*}{ Thuốc hóa dược } & Số lượng & 46 & 48 & 104,3 & $+0,4$ \\
\hline & Tỷ lệ(\%) & 98 & 96 & & \\
\hline & Giá trị (TĐ) & 134.784 & 116.768 & 85,7 & $-13,6$ \\
\hline & Tý lệ(\%) & 97,8 & 87,3 & & \\
\hline \multirow{4}{*}{ Thực phẩm chức năng } & Số lượng & 1 & 2 & 200 & +200 \\
\hline & Tỷ lệ(\%) & 2 & 4 & & \\
\hline & Giá trị (TĐ) & 4.212 & 4.920 & 116 & +16 \\
\hline & Tỷ lệ(\%) & 3 & 4 & & \\
\hline Tổng cộng & & $\begin{array}{c}47 \\
139.925\end{array}$ & $\begin{array}{c}50 \\
122.598\end{array}$ & $\begin{array}{c}106 \\
87,6 \%\end{array}$ & $\begin{array}{c}+6 \% \\
-12,4 \%\end{array}$ \\
\hline
\end{tabular}

Nhận xét: Với số lượng 47 thuốc và thực phẩm chức năng năm 2017, tổng doanh thu đạt được của Công ty TNHH dược phẩm Xuân Hòa là 139,95 tỷ đồng; Năm 2018 với số lượng 50 mặt hàng doanh thu đạt là 122,598 tỷ đồng tương đương 87,6\% so với năm 2017. Chiếm tỷ trọng lớn doanh thu hàng năm vẫn là chủng loại thuốc hóa dược lần lượt $98 \%$ và $96 \%$ tổng doanh thu bán hàng của công ty. Chủng loại thực phẩm chức năng chiếm tỷ trọng khiêm tốn là 4\%.

Cơ cấu hàng hóa của công ty năm 2017-2018

Bảng 3.2. Cơ cấu nhóm thuốc tân dược của công ty theo tác dụng dược lý

\begin{tabular}{|c|c|c|c|c|c|c|c|c|}
\hline \multirow[b]{2}{*}{ Nhóm Tác dụng } & \multicolumn{4}{|c|}{2017} & \multicolumn{4}{|c|}{2018} \\
\hline & $\begin{array}{c}\text { Số } \\
\text { lượng }\end{array}$ & \begin{tabular}{|l} 
Tỷ lề \\
$(\%)$
\end{tabular} & $\begin{array}{c}\text { Doanh } \\
\text { thu }\end{array}$ & $\begin{array}{l}\text { Tỷ lệ } \\
(\%)\end{array}$ & $\begin{array}{c}\text { Số } \\
\text { Iượng }\end{array}$ & $\begin{array}{l}\text { Tỷ lế } \\
(\%)\end{array}$ & $\begin{array}{l}\text { Doanh } \\
\text { thu }\end{array}$ & $\begin{array}{l}\text { Tỷ lệ } \\
(\%)\end{array}$ \\
\hline Thuốc điều trị mắt, tai mũi họng & 3 & 6,3 & 39.932 & 28,5 & 3 & 6 & 28.583 & 23,5 \\
\hline Tiêu & 2 & 4 & 22.394 & 16 & 2 & 4 & 14.994 & 12,3 \\
\hline Khoáng chất v & 11 & 23 & & 8,3 & 15 & 30 & 16.745 & 13.76 \\
\hline Chống nhiễm khuẩn & 6 & 12,7 & 15.224 & 10,8 & 5 & 10 & 24.754 & 20 \\
\hline Jung dịch điều chỉnh nước điện giải & 5 & 10,6 & 19.743 & 14,1 & 3 & 6 & 11.616 & 9,5 \\
\hline Kháng sinh & 6 & 12,7 & & 9,4 & 6 & 12 & 9.334 & 7,6 \\
\hline & 2 & 4,2 & & 6,4 & 2 & 4 & 5.920 & 4,8 \\
\hline Các nhóm t & 12 & 25 & 8708 & 6,2 & 14 & 28 & 9.739 & 8 \\
\hline Tống công & 47 & 100 & 139.925 & 100 & 50 & 100 & 122.598 & 100 \\
\hline
\end{tabular}

Nhận xét: Cơ cấu danh mục sản phẩm kinh doanh của công ty tập trung chủ yếu là 8 nhóm thuốc tân dược. Doanh thu bán hàng tập trung vào một số nhóm thuốc nắm vai trò chủ đạo là nhóm thuốc điều trị mắt, tai mũi họng với 3 sản phẩm đạt doanh thu là 28,583 tỷ đồng nămm 2018, giảm hơn so với nằm 2017 (doanh thu đạt 39,932 tỷ đồng). Tiếp theo là nhóm chống nhiễm khuẩn có 5 sản phẩm với doanh thu năm 2018 đạt 24,754 tỷ VND tăng hơn so với năm 2017 (doanh thu đạt 15,224 tỷ đồng). Hai nhóm này đi đâuu trong trong danh mục thuốc của công ty với các mặt hàng của các công ty cung cấp phù hợp thị trường.

Bảng 3.3: Nguôn gốc thuốc trong danh muc của Công ty:

\begin{tabular}{|c|c|c|c|c|c|}
\hline & Chì tiêu & 2017 & 2018 & \% đạt & Tăng/giảm \\
\hline \multirow{3}{*}{$\begin{array}{l}\text { Nhâp } \\
\text { khẩu }\end{array}$} & Số lượng khoản mục & 2 & 3 & 150 & $50 \%$ \\
\hline & Doanh thu (triệu đồng) & 9.026 . & 9.012 & $99,9 \%$ & $-0,01$ \\
\hline & Tỉ lệ \% & 6,4 & 7 & & \\
\hline \multirow{3}{*}{$\begin{array}{l}\text { Trong } \\
\text { nước }\end{array}$} & Số lượng khoản mục & 45 & 47 & 104 & $0,4 \%$ \\
\hline & Doanh thu (triêu đồng) & 130.899 & 113.586 & $86,7 \%$ & $-13,3 \%$ \\
\hline & Tỉ lệ \% & $93,5 \%$ & 93 & & \\
\hline & Tống cộng & $47(139.925)$ & $50(122.598)$ & & \\
\hline
\end{tabular}

Nhận xét: Cơ cấu doanh thu đối với nhóm hàng sản xuất trong nước năm 2017 có 45 sản phẩm, doanh thu đạt 130,899 tỷ đồng chiếm 93,5\%, năm 2018 có 47 sản phẩm và giá trị doanh thu đạt 113,586 tỷ chiếm tỷ lệ 93\% giảm 13,3\% so với năm 2017. Cơ cấu hàng nhập khẩu năm 2017 có 2 sản phẩm giá trị đạt được là 9,026, năm 2018 có 3 sản phẩm giá trị đạt được 9,012 tỷ.

$>$ Doanh thu bán hàng trong thầu và ngoài đấu thầu: 
Bảng 3.4 Doanh thu bán theo hình thức bán hàng

\begin{tabular}{|c|c|c|c|c|c|}
\hline \multirow[t]{2}{*}{ 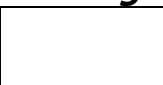 } & \multicolumn{3}{|c|}{ 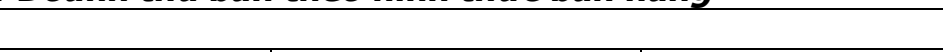 } & \multicolumn{2}{|c|}{ So sánh } \\
\hline & Chì tiêu & 2017 & 2018 & \% đạt & Tăng/giảm \\
\hline \multirow{4}{*}{ Đấu thâu } & Số lượng KH & 100 & 107 & 107 & $7 \%$ \\
\hline & Tỉ lệ (\%) & 45,2 & 46,9 & & \\
\hline & Doanh thu & 30.384 & 42.603 & 128 & $28 \%$ \\
\hline & Tỉ lệ (\%) & 21,7 & 34,7 & & \\
\hline \multirow{4}{*}{$\begin{array}{c}\text { Ngoài } \\
\text { đấu thầu }\end{array}$} & Số lượng KH & 121 & 121 & 100 & 0 \\
\hline & Tỉ lệ (\%) & 54,8 & 53,1 & & \\
\hline & Doanh thu & 109.541 & 79.995 & 73 & -27 \\
\hline & Tỉ lệ (\%) & 78,3 & 21,6 & & \\
\hline \multicolumn{2}{|c|}{ Tổng cộng } & $\begin{array}{c}221(139.925) \\
100 \%\end{array}$ & $\begin{array}{c}228(122.598) \\
100 \%\end{array}$ & & \\
\hline
\end{tabular}

Nhận xét: Năm 2018 công ty đã đẩy mạnh hơn kênh bán hàng đấu thầu từ 100 khách hàng 2017 lển 107 khách hàng năm 2018, tăng 7\%. Ngoài ra doanh thu cũng tăng từ 30,384 tỷ đồng năm 2017 lên 42,603 tỷ đồng năm 2018 (tăng 28\%). Khách hàng bán ngoài đấu thầu năm 2018 bằng với năm 2017, tuy nhiên doanh thu đạt được năm 2018 giảm 27\% (từ 109,541 năm 2017 tỷ xuống còn 79,995 tỷ đồng).

Bảng 3.5 Cơ cấu sản lượng, doanh thu và tỷ suât lợi nhuận gộp thuốc độc quyền phân phôi năm 2017 và năm 2018

\begin{tabular}{|c|c|c|c|c|c|c|c|c|}
\hline \multirow[b]{2}{*}{ Tên thuốc } & \multicolumn{4}{|c|}{2017} & \multicolumn{4}{|c|}{2018} \\
\hline & $\begin{array}{l}\text { Số lượng } \\
\text { (hộp) }\end{array}$ & $\begin{array}{c}\text { Doanh số } \\
\text { bán (triệu } \\
\text { đồng) }\end{array}$ & $\begin{array}{c}\text { Giá vốn } \\
\text { hàng } \\
\text { bán }\end{array}$ & $\begin{array}{l}\text { Lợi } \\
\text { nhuâân } \\
\text { gộp }\end{array}$ & $\begin{array}{c}\text { Số lượng } \\
\text { Hộp, }\end{array}$ & $\begin{array}{l}\text { Doanh } \\
\text { số bán } \\
\text { (triệu } \\
\text { đông) }\end{array}$ & $\begin{array}{c}\text { Giá } \\
\text { vốn } \\
\text { hàng } \\
\text { bán }\end{array}$ & $\begin{array}{c}\text { Lợi } \\
\text { nhuâan } \\
\text { gộp }\end{array}$ \\
\hline $\begin{array}{l}\text { Phong tê thấp } \\
\text { bà giăng } 400\end{array}$ & 74,960 & 5.388 & 4.500 & 16 & 57,433 & 4,250 & 3800 & 15 \\
\hline $\begin{array}{l}\text { Mezavitin - Hộp } \\
\text { 60viên }\end{array}$ & $10,578,380$ & 15.814 & 12.8 & 20 & $6,528,840$ & 9,933 & 7.94 & 21 \\
\hline $\begin{array}{c}\text { Natri clorid } \\
0,9 \% / 500 \mathrm{ml} \\
\end{array}$ & 458,200 & 4.202 & 2.941 & 30 & 0 & 0 & 0 & 0 \\
\hline $\begin{array}{c}\text { Natri clorid } \\
0.9 \% / 1000 \mathrm{ml}\end{array}$ & 146,972 & 1.979 & 1.700 & 14 & 0 & 0 & 0 & 0 \\
\hline $\begin{array}{l}\text { Povidon iod } \\
10 \% / 150 \mathrm{ml}\end{array}$ & 76,595 & 1.148 & 800 & 30 & 0 & 0 & 0 & 0 \\
\hline $\begin{array}{c}\text { Telzid 40/12.5 } \\
\text { Hôp } 60 \text { Viên }\end{array}$ & $6,435,240$ & 5.485 & 4.200 & 23 & $6,534,480$ & 4,279 & 3.400 & 21 \\
\hline Eganin & $1,301,785$ & 2.943 & 2.000 & 32 & 0 & 0 & 0 & 0 \\
\hline $\begin{array}{l}\text { Hypravas } 20 \\
\text { Hộp } 60 \text { Viên }\end{array}$ & $-1<0-1<0$ & 0 & 0 & 0 & $1,657,200$ & 1.643 & 1429 & 13 \\
\hline
\end{tabular}

Trong nhóm thuốc độc quyền của công ty từ năm 2017, sản phẩm Phong tê thấp Bà giằng 400, Mezavitin, Telzid 40/12.5 chiếm doanh thu cao trong cả 2 năm và có tỷ lệ lợi nhuận gộp lần lượt là $15 \%, 21 \%, 21 \%$ trong năm 2018 . Tuy nhiên, năm 2018 công ty đã có một số sản phẩm hết hợp đồng phân phối độc quyền mà có doanh thu cao là Natri clorid $0,9 \% / 500 \mathrm{ml}$ và Natri clorid $0.9 \% / 1000 \mathrm{ml}$, Povidon iod

$10 \% / 150 \mathrm{ml}$ và Eganin. Điều này đã ảnh hưởng tới hoạt động và hiệu quả kinh doanh của công ty trong năm 2018. Công ty đã cố gắng tìm kiếm sản phẩm thay thế là Hypravas nhưng tỷ suất lợi nhuận gộp chỉ đạt là $13 \%$.

Vốn và tài sản của Công ty TNHH Dược phẩm Xuân Hòa

Kết cấu nguồn vốn và tài sản của công ty được thể hiện tại bảng:

Bảng 3.6 Vốn và tài sản của Công ty TNHH Dược phẩm Xuân Hòa 2017-2018

\begin{tabular}{|c|c|c|c|}
\hline Chỉ tiêu & $\mathbf{2 0 1 7}$ (triệu đồng) & $\mathbf{2 0 1 8}$ (triệu đồng) & Tỷ lệ tăng trưởng (\%) \\
\hline Tống cộng vốn và tài sản & 34.397 & 43.060 & 120,1 \\
\hline Tài sản ngắn hạn & 32.188 & 41.310 & 128,8 \\
\hline Tỷ lệ trên tống tài sản $(\%)$ & 93,6 & 95,9 & \\
\hline
\end{tabular}


VIETNAM MEDICAL JOURNAL N²2 - JUNE - 2021

\begin{tabular}{|c|c|c|c|}
\hline Tài sản dài hạn & 2.208 & 1.750 & $-26 \%$ \\
\hline Tỷ lệ trên tổng tài sản (\%) & 6,8 & 3,1 & 104,2 \\
\hline Vốn chủ sở hữu & 10.130 & 10.142 & \\
\hline Hê̂ số tài trợ (VCSH/TNV) & 0,29 & 0,23 & \\
\hline Hệ số tài trợ tài sản dài hạn & 4,58 & 5,79 & \\
(VCSiH/ TSDH) & 4,58 & & \\
\hline
\end{tabular}

Nhận xét: Nhìn chung các chỉ số chính về tài sản và nguồn vốn của Công ty năm 2018 có sự tăng trưởng so với năm 2017. Tuy nhiên, tài sản dài hạn của công ty có sự sưt giảm là $26 \%$. Tổng nguồn vốn và tài sản 2018 đạt 43,060 tỷ tăng 120,1\% so với năm 2017. Trong kêt cấu tài sản, tài sản ngắn hạn chiếm tỷ trọng cao với 95,9\% và tăng trưởng mạnh. Hệ số tài trợ và hệ số tài trợ tài sản dài hạn chỉ đat 0,23 và 5,79 .

\section{Các chỉ số lợi nhuần}

Bảng 3.7 Mốt số chỉ tiêu lợi nhuân của công ty

\begin{tabular}{|c|c|c|}
\hline \multirow{2}{*}{ Chỉ tiêu } & $\mathbf{2 0 1 7}$ & $\mathbf{2 0 1 8}$ \\
\cline { 2 - 3 } & $\mathbf{( 1 )}$ & $\mathbf{( 2 )}$ \\
\hline Doanh thu thuần(triệu đồng) & 139.925 & 122.598 \\
\hline Vốn chú sở hữu (triệu đồng) & 10.130 & 10.142 \\
\hline Lợi nhuận sau thuế(triệu đông) & 123,7 & 11,8 \\
\hline Tống tài sản & 34.397 & 43.060 \\
\hline Tỷ suất LN/DTT (ROS) (\%) & 0.08 & 0.01 \\
\hline Tỹ suất LN/VCSH (ROE) (\%) & 1,2 & 0,11 \\
\hline Tý suất LN/TTS (ROA) (\%) & 0,35 & 0,03 \\
\hline
\end{tabular}

Nhâ̂n xét: Năm 2018 các chỉ số lợi nhuận đều thấp hơn so với 2017. Năm 2018 cứ 100 đồng doanh thu thuần được thực hiện thu được 0,01 đồng lợi nhuận. Điều đó cho thẩy tỷ suất lợi nhuận từ doanh thu đạt ở mức thấp. Tỷ suất lợi nhuẩn trên vốn chủ sở hữu (ROE) năm 2018 $(0,11)$ giảm so với năm $2017(1,2)$ là 1,09\%. Năm 2018 cứ 100 đồng VCSH thực hiện trong năm thì thu được 0,11 đồng lợi nhuận. Tỷ suất lợi nhuận trên tổng tài sản (ROA) giảm mạnh từ 0,35 năm 2017 xuống còn 0,03 năm 2018.

\section{BÀN LUÂ̂N}

Doanh thu của Công ty TNHH Dược phẩm Xuân Hòa năm 2018 đạt 122.598 tỷ đồng, đạt 87,61 so với năm 2017 (đạt 139.925 tỷ VND). Theo báo cáo của tổng quan về tỷ lệ tăng trưởng chung của ngành Dược giai đoạn 2015-2020 khoảng 10-14\% [4]. Như vậy năm 2018 doanh thu của Công ty TNHH dược phẩm Xuân Hòa chưa đạt mức tăng trưởng chung của toàn ngành dược, đây là tín hiệu không tốt đối với doanh nghiệp.

Nhóm thuốc Hóa dược kinh doanh của công ty năm 2018 là 48 sản phẩm đạt doanh thu là 116,768 tỷ VND chiếm tỷ trọng $87,3 \%$ thấp hơn so với công ty TNHH dược thảo Hoa hoa là 54 sản phẩm [5]. Nhóm hàng thực phẩm chức năng của công ty chỉ mới xâm nhập vào thị trường: Năm 2017 có 01 sản phẩm với doanh thu là 4,212 tỷ và năm 2018 có 02 sản phẩm đạt doanh thu là 4,920 tỷ VND.

Cơ cấu danh mục những sản phẩm kinh doanh của công ty tập trung chủ yếu 8 nhóm thuốc tân dược với doanh thu 122,598 tỷ đồng thấp hơn so với công ty TNHH Đại Bắc Miền Nam năm 2017, với 11 nhóm hàng tân dược và doanh thu đạt 214.113 tỷ đồng [8]. Công ty TNHH dược phẩm Xuân Hòa đã tập trung vào một số nhóm thuốc chính, trong đó hai nhóm chiến lược là nhóm thuốc điều trị măt, tai mũi họng với 3 sản phẩm chiếm doanh thu lớn nhất là 39.932 tỷ đồng năm 2017, và 28.583 tỷ đồng năm 2018. Tiếp theo là nhóm chống nhiếm khuẩn có 5 sản phẩm với doanh thu năm 2018 đạt 24,754 tỷ VND tăng hơn so với năm 2017 (doanh thu đạt 15,224 tỷ đồng). Hai nhóm này đi đầu trong trong danh mục thuốc của công ty và phù hợp với nhu cầu của thị trường.

Về cơ cấu danh mục thuốc kinh doanh theo nguồn gốc: sản phẩm sản xuất trong nước năm 2017 có 45 sản phẩm doanh thu đạt 130,899 tỷ chiếm 93,5\%, tới năm 2018 có 47 sản phẩm doanh thu đạt 113,586 tỷ đồng. Đối với nhóm hàng nhập khẩu năm 2017 có 2 sản phẩm, giá trị đạt được là 9,026 tỷ chiếm tỷ lệ $4 \%$ tổng doanh thu, năm 2018 có 3 sản phẩm giá trị đạt được 9,012 tỷ chiếm $6 \%$ tổng doanh thu. Như vậy, công ty đã tập trung kinh doanh các sản phẩn có nguồn gốc sản xuất trong nước phù hợp với chính sách ưu tiên sử dụng thuốc Việt nam [2, 3].

Năm 2017 công ty đã trúng thầu bệnh viện với 11 mặt hàng đạt danh thu 20,238 tỷ đồng. Tới năm 2018 công ty đã trúng thầu bệnh viện 15 mặt hàng thuốc đạt doanh thu là 29,457 tỷ đồng chiếm $25 \%$ (tăng $31,2 \%$ doanh thu của nhóm hàng trúng thầu bệnh viện). Nhóm ngoài bệnh viện trong năm 2017 gồm 36 thuốc đạt doanh thu là 119,687 tỷ đồng. Năm 2018 có 35 mặt hàng đạt doanh thu là 93,141 tỷ đồng (giảm $22,1 \%$ so với năm 2017). Tuy nhiên khi so sánh với công ty TNHH Dược phẩm Chân phúc, công ty TNHH dược phẩm Xuân Hòa trúng nhiều mặt hàng trong hình thức đấu thầu (15 sản phẩm so 
với 2 sản phẩm của công ty Chân Phúc) doanh thu bán thâu đạt 30,384 tỷ đồng năm 2017 và 42,603 tỷ đồng năm 2018. Xét mặ̆t bằng chung, công ty cũng đã phát triển rất tốt về mặt hàng đấu thầu. Khi so sánh lợi nhuận năm 2018 so với năm 2017 cho thấy lợi nhuận trước thuế năm 2018 đạt 26,6\% so với năm 2017 trong khi lợi nhuận sau thuế chỉ đạt $8,9 \%$. Nguyên nhân chủ yếu là năm 2018 công ty đã bị cắt một số sản phẩm phân phối độc quyền cho các bệnh viện nên đã ảnh hưởng nhiều tới doanh thu và lợi nhuận.

Tỷ suất lợi nhuận trên doanh thu thuần LN/DTT (ROS) đạt ở mức thấp $(0,01 \%$ năm 2018). Tỷ suất lợi nhuận trên VCSH (ROE) của Công ty năm 2018 đạt $0,11 \%$ nhỏ hơn $10 \%$ cho thây khả năng sinh lợi nhuận trên VCSH của doanh nghiệp là rất thấp. Khi so sánh với cùng kỳ năm 2017 chỉ số này giảm mạnh từ 1,2\% xuống 0,11\%.

Chỉ số tỷ suất LN/TTS (ROA) cho thây khả năng sinh lời trên tổng tài sản, Hai chỉ số này năm 2018 đạt $0,03 \%$ nhỏ hơn $10 \%$ cho thây Công ty hoạt động chưa hiệu quả. Khi so sánh với Công ty cổ phần Dược phẩm Vính Phúc năm 2017 chỉ số này là 5,2\% [7]; Công ty TV.Pharma năm 2017 có chỉ số ROA là 14,2\% và ROS là $11,4 \%$. Điều này cho thấy các chỉ số lợi nhuận của Công ty đang ở mức rất thấp.

Nhìn chung khi xét về lợi nhuận, hoạt động của Công ty năm 2018 không có hiệu quả bằng so với năm 2017, đây là tín hiệu xấu. Dẫn đến khi xem xét các chỉ số lợi nhuận cho thấy khả năng sinh lời của vốn và tài sản là không tốt.

\section{KẾT LUẬN}

Kết quả kinh doanh của công ty TNHH dược phẩm Xuân Hòa năm 2018 không tốt so với năm 2017. Doanh thu, lợi nhuận và tỷ suất lợi nhuận năm 2018 đều thấp hơn so với năm 2017 và với các chỉ số chung của ngành Dược. Công ty cần tìm kiếm thêm các nguồn hàng có lợi thế cạnh tranh để tăng hiệu quả kinh doanh của công ty trong các năm tiểp theo.

\section{TÀI LIÊU THAM KHẢO}

1. Bộ Y tế (2014), Chiến lược quốc gia phát triển ngành Dược Việt Nam Giai đoạn 2020 và tầm nhìn đến năm 2030 (kèm theo quyết định số 68/QĐTTG của Thủ tướng chính phủ ngày 10 tháng 01 năm 2014).

2. Bộ y tế (2016), Thông tư $11 / 2016 /$ TT-BYT Quy định việc đấu thấu thuốc tại cơ sở y tế công lập

3. Bộ Y tế (2018), Thông tư 30/2018/TT-BYT Ban hành danh mục và tỷ lệ, điều kiên thanh toán đối với thuốc hóa dược , sinh phẩm thuốc phóng xa và chất đánh dấu thuộc phạm vi được hưởng của người tham gia bảo hiểm y tế

4. Công ty chứng khoán ACBS (2018), Tổng quan Ngành - Dược phẩm 2018.

5. Lê Quang Dũng (2017), Phân tích kết quả kinh doanh của Công ty TNHH một thành viên thảo dược Hoa Hoa năm 2016, Chuyên Khoa I, Trường ĐH Dược Hà Nội.

6. Phạm Văn Dược Đăng Thị Kim Cương (2007), Phẩn tích hoat động kỉnh doanh, NXB Xã Hội, Hà Nội.

7. Nguyê̂n Vằn Luật (2018), Phân tích Kết quả kinh doanh Của chi nhánh công ty cổ phần dược phẩm vĩnh phúc - thành phố phúc yên năm 2017, Chuyên Khoa I, Trường ĐH Dược Hà Nội.

8. Văn Công Khanh (2018), Phân tích kết quả kinh doanh của công ty TNHH Đại Bắc Miền Nam Năm 2017.

\title{
HIÊUU QUẢ SỬ DƯNG SŨ̃A TƯƠI Bổ SUNG VI CHẤT TRONG CẢI THIÊ̂N Tİ̀NH TRANG THIẾU KẼM VÀ VITAMIN D TRÊN TRẺ TRƯờNG MẦM NON VÀ TIỂU HỌC NĂM 2018
}

\author{
Nguyễn Song Tú*, Nguyễn Thị Lâm*, \\ Trần Thúy Nga*, Hoàng Nguyễn Phương Linh*
}

\section{TÓM TẮT}

Bên cạnh cùng với vấn đề suy dinh dưỡng thể thấp còi, thì tình trạng thiếu vi chất dinh dương (VCDD) trẻ hoc đường còn ở mức cao có ý nghĩa sức khỏe cộng đồng. Nghiên cứu can thiệp cộng đồng ngẫu nhiên, có

*Viện Dinh dướng Quốc gia, Hà Nội

Chịu trách nhiệm chính: Nguyễn Song Tú

Email: nguyensongtu@yahoo.com

Ngày nhận bài: 12.4.2021

Ngày phản biên khoa học: 25.5.2021

Ngày duyệt bài: 14.6.2021 đối chứng tiến hành trong thời gian năm 2017 - 2018. Có 303 trẻ mầm non và tiểu hoc được sử dung sữa tươi bổ sung các vi chất và khoáng chất thiết yếu nhằm đánh giá hiệu quả đối với tình trạng thiếu VCDD. Sau 6 tháng can thiệp đã cải thiện có YNTK hàm lượng 25-hydroxyvitamin $D[25(\mathrm{OH}) \mathrm{D}]$ huyết thanh trung bình nhóm can thiệp so với nhóm chứng $(p<0,001)$; Đồng thời, tỷ lệ thiểu vitamin $D$ của nhóm can thiệp đã giảm (từ $89,4 \%$ xuống $74,8 \%$ ) có ý nghĩa thống kê (YNTK) so với nhóm chứng $(p<0,01)$. Tỳ lệ thiếu kẽm nhóm can thiệp giảm (từ 74,2\% xuống $63,3 \%$ ) có YNTK so với nhóm chứng (tăng lên từ 74,2 lên $83,9 \%)(p<0,001)$. Vì vậy, sử dụng sữa 